\title{
Anti-inflammatory effect of Distylium racemosum leaf biorenovate extract in LPS-stimulated RAW 264.7 macrophages cells
}

\author{
Hyehyun Hong ${ }^{1} \cdot$ Kyung-Mi Lee ${ }^{1} \cdot$ Taejin Park ${ }^{1} \cdot$ Won-Jae Chi ${ }^{2} \cdot$ Seung-Young Kim ${ }^{1}$

\section{LPS로 유도된 RAW 264.7 세포에 대한 조록나무 잎 Biorenovation 추출물의 항염증 활성}

홍혜현 ${ }^{1} \cdot$ 이경미 $^{1} \cdot$ 박태진 $^{1} \cdot$ 지원재 ${ }^{2} \cdot$ 김숭영 $^{1}$

Received: 10 September 2021 / Accepted: 15 October 2021 / Published Online: 31 December 2021

(C) The Korean Society for Applied Biological Chemistry 2021

\begin{abstract}
Biorenovation is a microbial enzyme-based structural modification of component compounds in natural products and synthetic compounds including plant extracts with the potential benefits of improved biological activities compared with its reaction substrates. In this study, we investigated the antiinflammatory activity of Distylium racemosum leaf extract and $D$. racemosum leaf biorenovation extract (DLB). As a result, DLB inhibited nitric oxide, prostaglandin E2, and inflammatory cytokines including tumor necrosis factor- $\alpha$, interleukin-6, interleukin-1 $\beta$ at non-toxic concentrations. In addition, DLB significantly inhibited inducible nitric oxide synthase and cyclooxygenase-2 on LPS-treated RAW 264.7 macrophages. Based on these results, we suggest that the DLB could be used as a potent anti-inflammatory agents. It also suggests that the application of biological evolution has potential usefulness to increase the practical value of natural products.
\end{abstract}

Seung-Young $\operatorname{Kim}(\triangle)$

E-mail: sykim01@sunmoon.ac.kr

${ }^{1}$ Department of Pharmaceutical Engineering \& Biotechnology, Sunmoon University, Asan 31460, Republic of Korea

${ }^{2}$ Genetic Resources Assessment Division, National Institute of Biological Resources, Incheon 22689, Republic of Korea

This is an Open Access article distributed under the terms of the Creative Commons Attribution Non-Commercial License (http://creativecommons. org/licenses/by-nc/3.0/) which permits unrestricted non-commercial use, distribution, and reproduction in any medium, provided the original work is properly cited.
Keywords Anti-inflammation · Biorenovation · Cyclooxygenase2 - Distylium racemosum . Inducible nitric oxide synthase

서 론

염증은 물리적 화학적 자극에 의한 외상이나 조직 손상으로부 터 신체를 방어하기 위한 생체 조직의 면역 반응으로, 다양한 면역세포에 의해 진행되는 일련의 생물학적 과정이다[1-3]. 일 반적으로 염증반응은 손상된 조직에서 여러 면역 관련 세포들 이 분비하는 nitric oxide (NO), prostaglandin (PG) 및 tumor necrosis factor- $\alpha$ (TNF- $\alpha$ ), interleukin-6 (IL-6), interleukin-1 $\beta$ (IL-1 $1 \beta$ )와 같은 전염증성 사이토카인(Pro-inflammatory cytokines) 을 포함한 다양한 염증 촉진성 매개 물질에 의해 유도되는데[46], 이들은 통증, 부종, 열 등의 염증성 증상을 발현하여 다양한 질병의 매개체로써 중요한 역할을 한다[7]. 체내의 주요 염증 세포로 알려진 대식세포 (Macrophage)는 세포 표면에 발현하는 toll-like receptor을 통해 gram negative bacteria의 외부 세포막 독소 물질인 lipopolysaccharide (LPS)를 인식하여 세포 내 전사 인자 nuclear factor- $\mathrm{\kappa B}(\mathrm{NF}-\kappa \mathrm{B})$ 의 신호 전달 경로를 활성화 하 는데, 대식세포의 핵 안으로 이동한 NF- $\mathrm{kB}$ 는 염증 관련 유전 자인 inducible nitric oxide synthase (iNOS) 및 cyclooxygenase-2 (COX-2)의 발현을 유도함으로써 NO 및 prostaglandin E2 $\left(\mathrm{PGE}_{2}\right)$ 와 같은 염증 매개 물질의 생성을 증가시킨다[8-10]. 그 중 $\mathrm{NO}$ 는 고 반응성 radical의 일종으로, 낮은 농도에서는 신호 전달 및 박테리아의 사멸을 통한 면역 작용 등의 인체의 중요 한 생리적역할을 수행하지만, 과도한 발현은 체내에 적절하지 않은 염증을 유발하여 유전자의 변이, 조직과 신경의 손상을 초 
래한다고 보고되고 있다[11,12]. 또한 $\mathrm{COX}-2$ 의 촉매적 활성을 증가시키고, signaling cascade를 촉발하는 등 COX-2의 급성적 인 발현을 유도하여 $\mathrm{PGE}_{2}$ 의 생성을 증가시킴으로써 여러 난치 성 질환을 유발하는 것으로도 보고되었다[13]. 이러한 염증성 질환의 원인이 되는 과도한 $\mathrm{NO}$ 와 $\mathrm{PGE}_{2}$ 의 생성이 유도형 $\mathrm{iNOS}$ 및 $\mathrm{COX}-2$ 에 의한 것임을 고려할 때. $\mathrm{iNOS}$ 와 $\mathrm{COX}-2$ 유전자 발현을 억제하는 물질이 염증반응 조절 소재로서의 활용 가능 성이 높다고 볼 수 있다[14,15]. 최근 다양한 질병의 염증성 근 거가 명확해짐에 따라 염증성 질환의 예방 및 치료를 목적으로 한 iNOS, COX-2 및 여러 염증 매개 물질의 활성 억제에 대한 관심이 높아지고 있으며, 보다 안전한 항염증 소재의 발굴을 위 한 연구가 활발히 진행되고 있다[16,17].

본 연구에서 사용된 조록나무는 조록나무과의 상록 교목으로 제주도 및 남해의 섬 등에 자생하며, 일본 혼슈 이남, 중국 동 남부, 타이완 등에 분포한다. 또한, 항염증 효능이 있다고 보고 된 syringin과 catechin, quercetin, quercitrin 등과 같은 생리활 성성분을 함유하는 것으로 알려져 있으며[18], DPPH 라디칼 소 거능을 통한 항산화 효능과 tyrosinase 및 elastase의 억제 효능 이 연구되었다[19,20]. Kim 등[21]의 연구 결과에 의하면 조록 나무 잎 추출물의 NO 생성 억제 효능은 미미한 것으로 보고되 었으나 다양한 염증 인자에 대한 연구는 보고되지 않았다.

최근 산업 발전과 함께 피부 미용에 대한 관심이 증가하여 활발한 연구가 진행되고 있으나, 유해 성분 및 합성 성분에 대 한 부작용으로 인하여 화학 물질에 대한 공포증을 가진 케미컬 포비아 (Chemical Phobia) 등의 신종 문화가 확산되고 있으며, 부작용이 적거나 천연 소재에 대한 관심이 증가되고 있다[22]. 또한, 독성이 있거나 활성이 미미하여 가치가 낮은 천연물을 대 상으로 생리활성을 증진시키기 위한 연구가 활발하게 이루어지 고 있는 가운데, 미생물 효소 반응을 통해 새롭게 유도함으로 서 천연물의 활성을 증진시키는 biorenovation은 토란 및 유채 추출물 등 다양한 천연물에 적용되어 그 유용성을 입증 한 바 있다[23,24]. 이에 본 연구는 LPS로 자극된 RAW264.7 염증 모델에서 조록나무 잎 추출물 (DL)에 biorenovation을 적용한 추출물 (DLB)의 NO, iNOS, COX-2 및 전염증성 사이토카인 억제 효과를 조사함으로서 효과적인 천연 항염증제로서의 활용 가능성을 검토하고자 한다.

\section{재료 및 방법}

\section{조록나무 잎 추출물 제조}

본 실험에 사용된 조록나무 잎은 2020년 8월에 제주도 서귀포 시 남원읍 신례리에서 채취하였다. 건조된 조록나무 잎은 분쇄 하여 $70 \%$ ethanol 추출하였으며, 분말 $1 \mathrm{~g}$ 에 $70 \%$ ethanol 500 $\mathrm{mL}$ 을 가하여 실온에서 48 시간 동안 2 회 반복하여 추출하였다. 이 후 추출액을 paper filter (TOYO ROSHI KAISHA, Tokyo, $\mathrm{Japan)로} \mathrm{여과하였으며,} \mathrm{여과액을} \mathrm{감압농축기로} \mathrm{농축한} \mathrm{뒤,}-110$ ${ }^{\circ} \mathrm{C}$ 에서 동결 건조하여 분말로 제조하였다.

\section{미생물 배양 및 biorenovation 반웅}

Biorenovation을 위한 미생물은 제주도 콩 재래 간장에서 분리 한 Bacillus sp. JD3-7균주(KACC 92346P)를 사용하였으며, 최
등[25]에서 기술한 방법에 따라 genistein을 기질로 하는 생물전 환 기반 스크리닝법을 통해 HPLC 분석한 결과, 가장 높은 전 환률을 보인 균주로 선정하였다. Nutrient broth (Peptone 5.0 $\mathrm{g} / \mathrm{L}$, Beef extract $3.0 \mathrm{~g} / \mathrm{L}$ )를 이용하여 $30^{\circ} \mathrm{C}$ 에서 18 시간 동안 배양 하였다. 이후 $4,000 \mathrm{rpm}$ 에서 15 분간 원심분리하여 회수한 균체를 2회 세척한 뒤, PG buffer $(50 \mathrm{mM}$ Phosphate buffer, $2 \%$ Glycerin) $100 \mathrm{~mL}$ 에 현탁 하였으며, 기질을 넣지 않고 Bacillus sp. JD3-7 균체를 현탁한 대조군 (BJ)과 조록나무 잎 추출물 (DL) $100 \mathrm{mg}$ 첨가한 flask를 $30^{\circ} \mathrm{C}$ 에서 72 시간 동안 동일한 조건하에 biorenovation 반응하였다. 반응 종료 후 원심 분리하여 pellet과 상등액을 분리한 뒤, pellet을 제거한 상등액 을 $-110^{\circ} \mathrm{C}$ 에서 동결 건조하여 실험에 사용하였다.

\section{Biorenovation 전환물의 HPLC 분석}

시료의 HPLC 분석을 위하여 Shimadzu SpectroMonitor 3200 digital UV/Vis detector를 사용하였으며, $0.1 \%$ Trifluoroacetic acid (TFA, SAMCHUN, Pyeongtaek, Korea)가 첨가된 $\mathrm{H}_{2} \mathrm{O}$ (Solvent A)와 acetonitrile (Solvent B, Sigma-Aldrich, St. Louis, MO, USA)를 용매로 하였다. 분석 조건은 column (Phenomenex $4 \mu \mathrm{m}$ Hydro-RP $80 \AA, 250 \times 4.6 \mathrm{~mm}$ ), 온도 40 ${ }^{\circ} \mathrm{C}$, 유속 $1.0 \mathrm{~mL} / \mathrm{min}$ 으로 $254 \mathrm{~nm}$ 파장에서 실시하였으며, 조록 나무 잎 추출물 (DL)과 biorenovation 생물전환 된 조록나무 잎 추출물(DLB) 그리고 대조군(BJ)를 dimethyl sulfoxide (DMSO, Sigma-Aldrich)로 용해하였다. 시료는 30 분간 gradient 조건으로 분석하였으며, 용매의 구배는 acetonitrile (Solvent B)을 0.1 $\min : 10 \%$ 에서 $30 \mathrm{~min}: 100 \%$ 가 되도록 하였다.

\section{실험 재료 및 세포배양}

연구에 사용된 LPS는 Sigma-Aldrich에서 구입하였으며, RAW 264.7 세포는 한국세포주은행에서 분양 받아, $10 \%$ fetal bovine serum (FBS, Gibco, Grand Island, NY, USA)과 $100 \mathrm{U} / \mathrm{mL}$ penicillin, $100 \mu \mathrm{g} / \mathrm{mL}$ streptomycin을 함유된 Dulbecco's Modified Eagle Medium (Gibco) 배양액을 사용하여 $37^{\circ} \mathrm{C}, 5 \% \mathrm{CO}_{2}$ 조 건의 incubator 에서 배양 하였으며, 2 일을 주기로 계대 배양 하였다.

\section{세포 독성 측정}

RAW 264.7 세포에 대한 시료의 세포 독성은 MTT assay를 이 용한 cell viability assay를 통해 측정하였다. 24-well plates에 RAW 264.7 세포를 $7.0 \times 10^{4}$ cells/well의 농도로 접종하여 37 ${ }^{\circ} \mathrm{C}, 5 \% \mathrm{CO}_{2}$ incubator에서 24 시간 동안 전 배양한 후, 배양 배 지로 희석한 시료 $(6.25,12.5,25 \mu \mathrm{g} / \mathrm{mL})$ 와 LPS $(1 \mu \mathrm{g} / \mathrm{mL})$ 를 동시 처리하여 동일한 배양 조건하에 24시간 동안 염증을 유도 하였다. 그 후 MTT 시약을 첨가하여 incubator에서 3시간 동 안 반응하였으며, 각 well에 형성된 formazan blue를 DMSO로 용해시킨 후 ELISA reader를 이용하여 $570 \mathrm{~nm}$ 파장에서 흡광 도를 측정하였다.

\section{NO 생성 억제 활성 측정}

RAW 264.7 세포를 24-well plates에 $7.0 \times 10^{4}$ cells/well의 농도 로 접종하여 $37^{\circ} \mathrm{C}, 5 \% \mathrm{CO}_{2}$ incubator 에서 24시간 동안 전 배양한 후 LPS $(1 \mu \mathrm{g} / \mathrm{mL})$ 와 희석 된 시료 $(6.25,12.5,25 \mu \mathrm{g} /$ 
$\mathrm{mL}$ )를 동시 처리하여 동일한 배양 조건하에 24 시간 동인 염증 을 유도하였다. 이후 배양액 $100 \mu \mathrm{L}$ 에 Griess 시약 $[1 \%(\mathrm{w} / \mathrm{v})$ sulfanilamide, $0.1 \%(\mathrm{w} / \mathrm{v})$ naphylethylenediamine in $2.5 \%(\mathrm{v} / \mathrm{v})$ phosphoric acid] $100 \mu \mathrm{L}$ 를 96-well plates에서 혼합하여 15 분간 암반응 시킨 후, ELISA reader를 사용하여 $540 \mathrm{~nm}$ 파장에서 흡광도를 측정하였다.

\section{Prostaglandin $\mathrm{E}_{2}\left(\mathrm{PGE}_{2}\right)$ 생성 억제 활성 측정}

RAW 264.7 cell 을 24-well plates에 $7.0 \times 10^{4}$ cells/well 농도 로 접종하여 $37{ }^{\circ} \mathrm{C}, 5 \% \mathrm{CO}_{2}$ incubator에서 24시간 동안 전 배 양한 후, LPS $(1 \mu \mathrm{g} / \mathrm{mL})$ 와 희석된 시료 $(6.25,12.5,25 \mu \mathrm{g} / \mathrm{mL})$ 를 동시 처리하여 동일한 조건하에 24시간 동안 염증을 유도하 였다. 이후 회수한 배양액을 $10,000 \mathrm{rpm}$ 에서 3 분 동안 원심분 리하여 침전물을 제거한 뒤, 상등액을 회수하여 실험에 사용하 였으며, 상등액에 존재하는 $\mathrm{PGE}_{2}$ 의 함량은 mouse enzymelinked immnunosorbent assay (ELISA) kit (R\&D Systems Inc., Minneapolis, MN, USA)를 이용하여 측정하였다.

\section{Western blot analysis}

RAW 264.7 cell을 6-well plates에 $5 \times 10^{5}$ cells/well의 농도로 접종하여 $37^{\circ} \mathrm{C}, 5 \% \mathrm{CO}_{2}$ incubator에서 24시간 동안 전 배양 한 후, 희석 된 시료 $(6.25,12.5,25 \mu \mathrm{g} / \mathrm{mL})$ 와 LPS $(1 \mu \mathrm{g} / \mathrm{mL})$ 를 동시 처리하여 동일한 조건하에 24시간 동안 염증을 유도하 였다. 이후 세포를 PBS로 2회 세척한 뒤, lysis buffer [1 $\times$ RIPA (Upstate Cell Signaling Solution, Danvers, NY, USA), $1 \mathrm{mM}$ phenylmethylsulfonyl fluoride, $1 \mathrm{mM} \mathrm{Na} \mathrm{VO}_{4}$, $1 \mathrm{mM} \mathrm{NaF}, 1 \mu \mathrm{g} / \mathrm{mL}$ aprotinin, $1 \mu \mathrm{g} / \mathrm{mL}$ pepstatin, and $1 \mu \mathrm{g} /$ $\mathrm{mL}$ leupeptin]로 처리하여 1시간 동안 lysis를 진행 하였으며, 이후 원심 분리 $(12,000 \mathrm{rpm}, 30 \mathrm{~min})$ 과정을 거쳐 상등액과 pellet을 분리하였다. 상등액의 단백질 농도는 $\mathrm{BCA}$ kit (Bio$\mathrm{Rad}$, Hercules, CA, USA)를 사용하여 정량 하였으며, $20 \mu \mathrm{g}$ 의 단백질을 $10 \%$ polyacrylamide를 함유한 $10 \%$ SDS-PAGE에서 전기영동 한 후, poly-vinylidene difluoride membrane (Milipore, Burlington, $\mathrm{MA}, \mathrm{USA}$ )에 전이하였다. 전이가 종료 된 membrane은 5\% skim Milk (sol. TBST)에 넣고 상온에서 2시 간동안 blocking을 실시하였으며, TBST로 10 분간 3 회 세척한 뒤, TBST로 희석된 1차 항체(iNOS antibody (1:1,000, BioRad), COX-2 antibody (1:1,000, Rockland Immunochemicals, Inc., USA), $\beta$-actin antibody clone AC-74 (1:10,000, Sigma) 에 담구어 $4{ }^{\circ} \mathrm{C}$ 에서 overnight하였다. 반응이 끝난 후 TBST 용 액으로 4회 세척한 membran을 horseradish peroxidase가 결합 된 2차 항체(Jackson ImmunoResearch, West Grove, PA, USA)를 $1: 10,000$ 비율로 희석하여 90 분 동안 반응하였으며, 반 응 종료 후 다시 TBST로 10 분간 3 회 세척한 뒤, ECL kit (Bio-Rad)와 반응시켜 imaging densitometer (model GS-700, $\mathrm{Bio}-\mathrm{Rad}$ )를 통해 현상하였다. 현상된 $\mathrm{iNOS}$ 와 $\mathrm{COX}-2$ 의 발현량 은 imageJ program (NIH, Bethesda, MD, USA)을 이용하여 $\beta$-actin 대비 iNOS와 COX-2의 면적을 정량화하여 그래프로 나 타내었다.

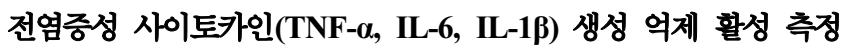
264.7 세포를 24-well plates에 $7.0 \times 10^{4}$ cells/well의 농도로 접종 하여 $\mathrm{CO}_{2}$ incubator $\left(37^{\circ} \mathrm{C}, 5 \% \mathrm{CO}_{2}\right)$ 조건에서 24 시간 배양한 후, 희석 된 시료 $(6.25,12.5,25 \mu \mathrm{g} / \mathrm{mL})$ 와 $\mathrm{LPS}(1 \mu \mathrm{g} / \mathrm{mL})$ 를 동시 처리하여 동일한 조건하에 24시간 동안 염증을 유도하였 다. 이후 회수한 배양 배지를 원심분리 $(10,000 \mathrm{rpm}, 3 \mathrm{~min})$ 하여 침전물을 제거하였으며, 침전물을 제거한 상등액을 이용하여 배 양액 내에 존재하는 전염증성 사이토카인의 함량을 측정하였 다. 측정에는 Mouse TNF- $\alpha$ ELISA Kit (Invitrogen, Carlsbad, CA, USA), Mouse IL-6 ELISA Kit (BD Biosciences, San Jose, CA, USA), Mouse IL-1 $\beta$ ELISA Kit (R\&D Systems Inc.)를 이용하였다.

\section{통계처리}

모든 실험은 3 회 반복하여 측정하였고, 그 결과는 평균값 \pm 표 준편차로 나타냈으며 통계적 분석은 각 처리 구간의 유의성 $\left({ }^{*} p<0.05 ;{ }^{* *} p<0.01\right)$ 을 검증을 위해 분산분석 (analysis of variance, ANOVA)후 student's t-test로 다중 비교를 실시하였다.

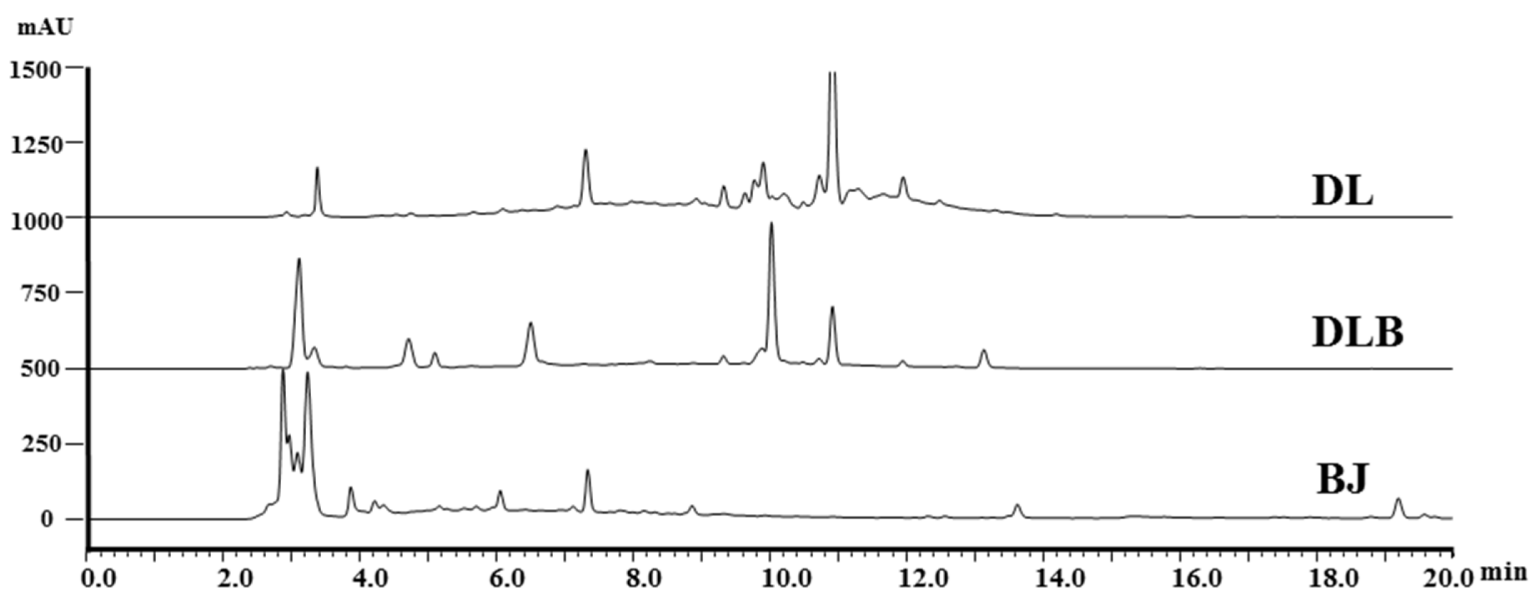

Fig. 1 HPLC Chromatogram of D. racemosum leaf extract (DL), D. racemosum leaf Biorenovate Extract (DLB) and Bacillus sp. JD3-7 (BJ). The chromatogram showed DL, DLB, and BJ 
결 과

\section{Biorenovation 전환물의 HPLC 분석}

조록나무 잎 추출물을 기질로 biorenovation 생물 전환 하여 얻 은 반응액을 원심분리 $(4,000 \mathrm{rpm}, 15 \mathrm{~min})$ 하여 cell pellet과 상 등액으로 분리한 뒤, pellet을 제거한 상등액을 동결건조하여 실 험에 사용 하였다. 조록나무 잎 추출물(DL), 생물 전환 된 조 록나무 잎 추출물(DLB)과 생물 전환에 이용한 미생물 Bacillus sp. JD3-7 (BJ)를 대조군으로 하여 HPLC 분석을 진행한 결과, $\mathrm{DLB}$ 에서 기존 $\mathrm{DL}$ 추출물에서는 검출되지 않은 신규 peak의 존재를 확인하였으며, $10.05 \mathrm{~min}$ 에서 가장 큰 peak가 확인되었 다(Fig. 1). Koiralal 등[26]에서 연구된 결과에 따르면 biorenovation 은 naringenin로부터 naringenin 7-O-phosphate, naringenin 7O-glucoside 및 6"-O-succinylpruin와 같은 유도체의 생성을 촉 매 하는 것으로 보고 되었다. 따라서 조록나무 내 존재하는 다 양한 성분에서도 이와 같은 구조적 변화가 유도되었을 것으로 판단되며, DL (10. $94 \mathrm{~min})$ 의 전구체가 DLB (10. $05 \mathrm{~min})$ 의 유도체로 전환되었을 가능성을 시사한다.

\section{세포 독성 비교 측정}

LPS에 의해 유도된 RAW264.7 세포에서 DL, DLB 및 BJ의 세포 생존율을 조사하기 위해 MTT assay를 수행하였다. 각 시 료를 $6.25,12.5,25 \mu \mathrm{g} / \mathrm{mL}$ 농도로 처리하여 세포 생존율을 확 인한 결과, $25 \mu \mathrm{g} / \mathrm{mL}$ 내에서 $\mathrm{DL}, \mathrm{DLB}$ 은 $85 \%$ 이상의 세포 생존율이 나타내었으며, BJ 또한 $80 \%$ 이상의 세포생존율이 확 인되었다(Fig. 2). 따라서 본 실험의 결과를 바탕으로 추후 실 험은 세포 독성을 보이지 않는 $25 \mu \mathrm{g} / \mathrm{mL}$ 을 최대 농도로 하여 진행하였다.

\section{NO 생성 억제 활성 비교}

LPS에 의해 유도된 염증 반응에서 대식세포로부터 생성 및 분 비되는 $\mathrm{NO}, \mathrm{PGE}_{2}$, leukotriene, 전염증성 사이토카인과 같은 2 차 매개물들은 선천성, 후천성 면역을 조절하는데 중요한 역할 을 하는 것으로 알려져 있다[27]. 그 중에서 특히 iNOS에 의해

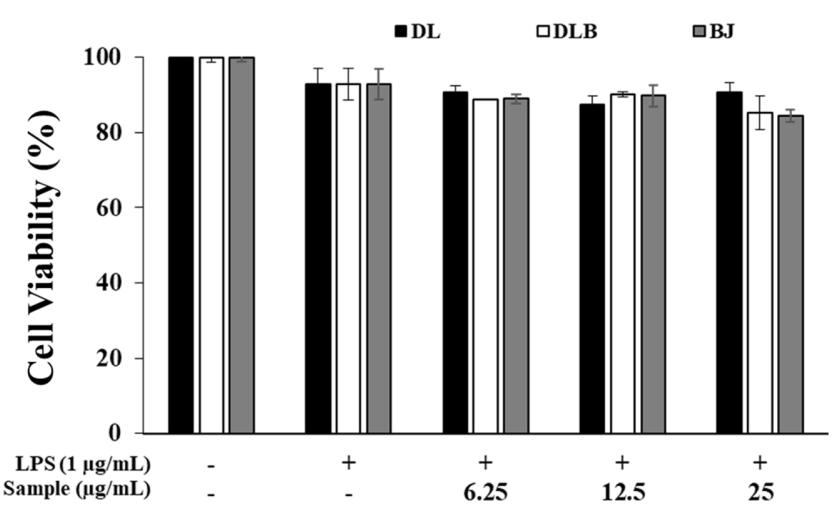

Fig. 2 Inhibitory effects of DL, DLB, and BJ on cell viability in RAW 264.7 cells. The production of nitric oxide was assayed in the culture medium of cells stimulated with LPS $(1 \mu \mathrm{g} / \mathrm{mL})$ for $24 \mathrm{~h}$ in the presence of DL or DLB or BJ $(6.25,12.5$, and $25 \mu \mathrm{g} / \mathrm{mL})$. Cytotoxicity was determined by MTT assay. Result is expressed as percentages compared to the respective values obtained for the control

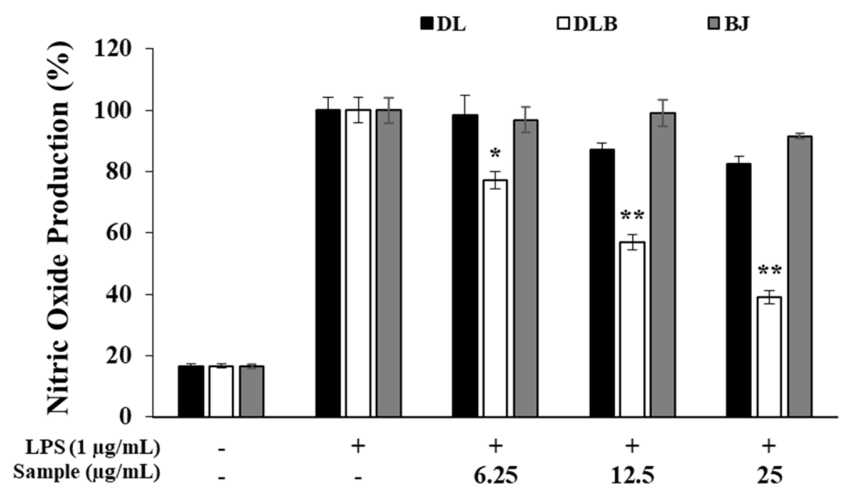

Fig. 3 Inhibitory effects of DL, DLB, and BJ on nitric oxide production in RAW 264.7 cells. The production of nitric oxide was assayed in the culture medium of cells stimulated with LPS $(1 \mu \mathrm{g} / \mathrm{mL})$ for $24 \mathrm{~h}$ in the presence of DL or DLB or BJ extract $(6.25,12.5$, and $25 \mu \mathrm{g} / \mathrm{mL})$. Result is expressed as percentages compared to the respective values obtained for the control. Data represent the means $\pm \mathrm{SD}$ with three separate experiments. ${ }^{*} p<0.05 ;{ }^{* *} p<0.01$

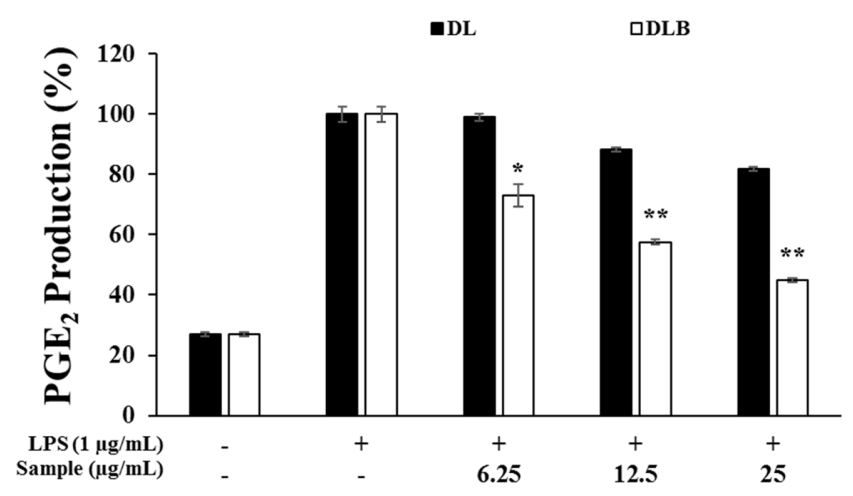

Fig. 4 Inhibitory effects of DL and DLB extract on $\mathrm{PGE}_{2}$ production in RAW 264.7 cells. The production of $\mathrm{PGE}_{2}$ was assayed in the culture medium of cells stimulated with LPS $(1 \mu \mathrm{g} / \mathrm{mL})$ for $24 \mathrm{~h}$ in the presence of DL and DLB extract $(6.25,12.5$, and $25 \mu \mathrm{g} / \mathrm{mL})$. Result is expressed as percentages compared to the respective values obtained for the control. Data represent the means $\pm \mathrm{SD}$ with three separate experiments. ${ }^{*} p<0.05 ;{ }^{* *} p<0.01$

생성된 $\mathrm{NO}$ 는 병리학적으로 중요한 의미를 갖는데, 높은 농도 의 $\mathrm{NO}$ 는 염증매개체의 생합성을 촉진하여 염증 반응을 촉진할 뿐만 아니라 DNA의 손상, 염증 증폭, 패혈성 쇼크 및 세포의 괴사를 유발하는 등 다양한 면역 질환의 원인으로 보고된 바 있다[28]. 따라서 $\mathrm{NO}$ 를 특이적으로 억제하는 물질은 다양한 면 역 질환을 효과적으로 예방 및 치료 할 수 있음을 의미한다. 이 에 본 실험은 RAW264.7 세포에서 LPS 자극에 의해 증가된 $\mathrm{NO}$ 의 생성에 대해 DLB가 미치는 영향을 알아보고자 수행되었 으며, LPS $(1 \mu \mathrm{g} / \mathrm{mL})$ 와 DL, DLB 및 $\mathrm{BJ}$ 를 $6,25,12.5,25$ $\mu \mathrm{g} / \mathrm{mL}$ 농도로 동시 처리한 뒤, griess reagent (Sigma-Aldrich, St. Louis, USA)를 이용하여 세포 배양액에 존재하는 $\mathrm{NO}^{2}$ 의 양을 측정하였다. 측정 결과, DLB는 LPS 단독 처리군 대비 $\mathrm{NO}$ 생성을 $22.9 \pm 2.8,43.1 \pm 2.5 \%$ 억제 하였으며, 가장 고농도인 $25 \mu \mathrm{g} / \mathrm{mL}$ 농도에서는 $61.1 \pm 2.2 \%$ 로, 모든 농도에서 유의적인 억 제 활성이 관찰되었다. 반면 $\mathrm{DL}$ 에서는 유의한 억제 활성이 관 

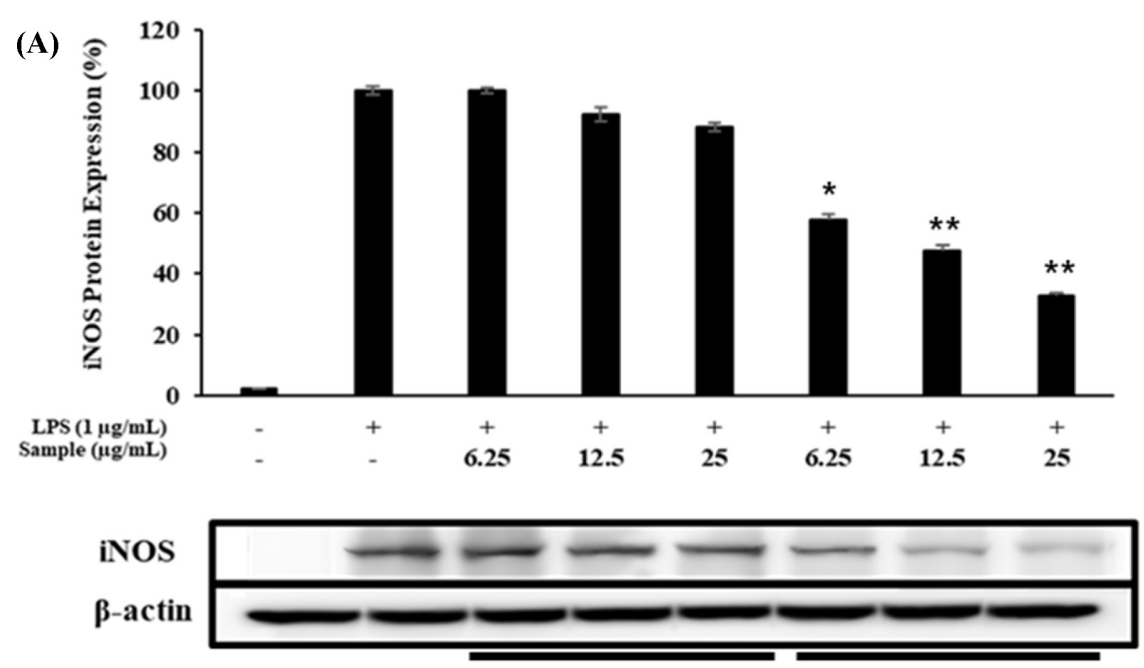

DL

DLB

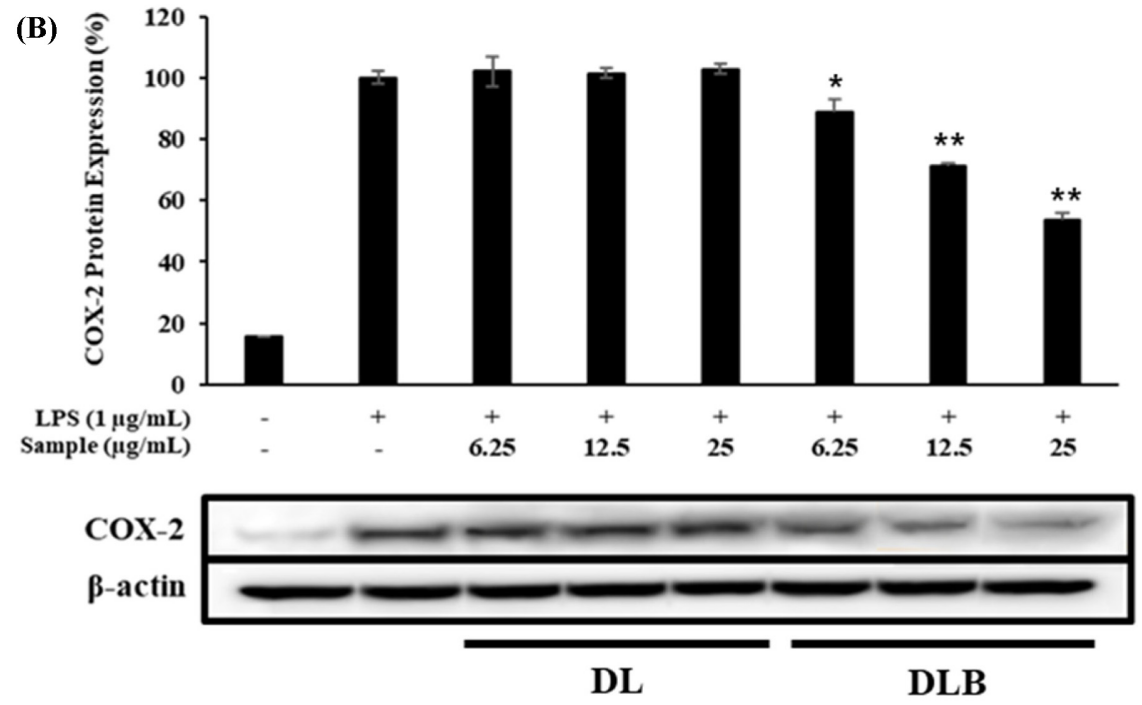

Fig. 5 Inhibitory effects of DL and DLB extract on the protein level of iNOS and COX-2 expression in LPS-stimulated RAW 264.7 cells. a) iNOS, b) COX-2. Cells $\left(5 \times 10^{5}\right.$ cells $/$ well $)$ were pre-incubated for $18 \mathrm{~h}$, and then treated with LPS $(1 \mu \mathrm{g} / \mathrm{mL})$ and Sample for $24 \mathrm{~h}$. The protein levels of iNOS, COX-2 were analyzed by western blot. $\beta$-actin was used as the control. Data represent the means \pm SD with three separate experiments. ${ }^{*} p<0.05$; $* * p<0.01$

찰되지 않았으며, $\mathrm{BJ}$ 또한 유의적인 억제 활성이 관찰되지 않 았다(Fig. 3). 이는 $\mathrm{DLB}$ 의 활성이 $\mathrm{BJ}$ 와는 무관한 고유의 효과 이며, DL대비 $\mathrm{DLB}$ 의 $\mathrm{NO}$ 억제 효능이 향상되었음을 시사한다. 따라서 $\mathrm{DLB}$ 는 $\mathrm{NO}$ 억제 기전을 통한 효과적인 항염증 소재라 사료된다.

\section{$\mathrm{PGE}_{2}$ 생성 억제 활성}

$\mathrm{PGE}_{2}$ 는 체내 면역반응의 조절자로서의 대식세포에서 TNF- $\alpha$, IL$1 \beta, \mathrm{IL}-8, \mathrm{IL}-12$ 등의 염증성 사이토카인의 생성을 억제하고, IL-10과 같은 항염증성 사이토카인의 생성을 촉진하는 등 면역 반응에 중요한 역할을 수행한다[29]. 그러나 체내 염증과정에서 $\mathrm{COX}-2$ 에 의해 과잉 생산되는 $\mathrm{PGE}_{2}$ 는 혈관 확장, 부종, 발열, 통증 등을 매개 함으로써 염증의 심화에 관여하는 것으로 보고
되었으며, angiogenesis를 촉진하는 등 암 발생에도 깊이 관여 하는 것으로도 알려져 있다[30], 이에 본 실험은 LPS 자극에 의해 유도된 RAW 264.7 세포에서 DLB가 $\mathrm{PGE}_{2}$ 의 생성에 미 치는 영향을 조사하기 위해 수행되었다. 실험 결과, DLB는 LPS 단독 처리군 대비 $\mathrm{PGE}_{2}$ 의 생성을 $27.1 \pm 3.7,43.4 \pm 0.9,55.3 \pm 0.7 \%$ 억제하였으며, DL을 처리한 RAW264.7에서는 유의한 감소경향 이 관찰되지 않았다(Fig. 4). 따라서 DLB는 biorenovation 과정 을 통해 기존의 추출물 대비 $\mathrm{PGE}_{2}$ 생성 억제 효능이 향상되었 으며, $\mathrm{PGE}_{2}$ 생성 억제를 통한 염증 반응의 개선에 기여할 수 있을 것으로 사료된다.

iNOS 및 COX-2 발현 억제

염증 유도 유전자인 iNOS 및 $\mathrm{COX}-2$ 는 염증과 같은 병적인 환 
경에서 대식세포 등 면역 관련 세포의 활성을 유도하여 염증반 응을 일으키는 원인 물질로 알려져 있다. 그 중 $\mathrm{NO}$ 는 고 반응 성의 생체 생성 radical의 일종으로, 대표적인 염증 반응의 지 표로서 알려져 있는데, 염증 반응에서 생성되는 $\mathrm{NO}$ 는 대부분 $\mathrm{iNOS}$ 의 작용에 의해 L-arginine과 $\mathrm{O}_{2}$ 로부터 합성된다고 보고되 었으며[31], 이는 iNOS의 발현이 $\mathrm{NO}$ 의 생성과 밀접한 연관이 있음을 시사한다. 또한 $\mathrm{COX}-2$ 는 염증반응에 관여하는 중요 인 자 중 하나인 $\mathrm{COX}$ 의 inducible isoform으로, 병리학적 염증반 응에서 급성적으로 발현되어 통증, 발열에 관여하는 염증 매개 체인 $\mathrm{PGE}_{2}$ 를 합성함으로써 염증반응에 관여하고 다양한 난치 성 질환을 유발하는 것으로 알려져 있다[32]. 따라서 iNOS 및 $\mathrm{COX}-2$ 유전자 발현은 $\mathrm{NO}$ 및 $\mathrm{PGE}_{2}$ 에 의해 염증성 매개물들이 과잉 생성되는 중요한 메커니즘이며, 만성적인 염증 반응을 예 방하기 위해 정확하게 제어 되어야 한다. 이에 본 실험에서는 $\mathrm{NO}$ 와 $\mathrm{PGE}_{2}$ 의 생성에 관여하는 $\mathrm{iNOS}$ 및 COX-2 단백질의 발 현에 DLB가 미치는 영향과 이들의 상관관계를 조사하고자 western blot assay를 수행하였다. LPS $(1 \mu \mathrm{g} / \mathrm{mL})$ 로 자극한 RAW 264.7 세포에 DL 및 DLB를 $6.25,12.5,25 \mu \mathrm{g} / \mathrm{mL}$ 농 도로 처리하여 24시간 염증을 유도한 후 $\mathrm{iNOS}$ 및 COX-2의 발현을 확인한 결과, DL을 처리한 RAW 264.7세포에서는 LPS 단독 처리군 대비 유의적인 감소 활성이 확인되지 않은 반면 $\mathrm{DLB}$ 를 처리한 RAW 264.7세포에서는 iNOS의 발현이 유의하 게 감소하는 것을 확인 하였다. 또한 DLB에 의한 iNOS의 발 현 감소와 $\mathrm{NO}$ 억제 경향이 유사한 것으로 보아 $\mathrm{NO}$ 감소활성 이 $\mathrm{iNOS}$ 의 발현과 밀접한 관련이 있음을 확인 하였다(Fig. $5 \mathrm{~A}$ ). 마찬가지로 DLB를 처리한 RAW 264.7세포에서 COX-2의 발현을 유의하게 억제되었으며, 그 경향이 $\mathrm{PGE}_{2}$ 의 감소 경향과 유사함을 확인하였다(Fig. $5 \mathrm{~B}$ ). 이와 같은 결과를 바탕으로 $\mathrm{DLB}$ 의 $\mathrm{NO}$ 및 $\mathrm{PGE}_{2}$ 억제 활성은 $\mathrm{iNOS}$ 와 $\mathrm{COX}-2$ 의 유전자 발현 감소로부터 기인한 것이며, 이들의 작용 기전을 표적으로 하는 효과적인 항염증 소재라 사료된다.

\section{전염중성 사이토카인 생성 억제}

염증매개인자에 의해 활성화된 대식세포가 생성 및 분비하는 전 염증성 사이토카인은 다른 cytokines의 생성을 유도함으로써 초 기 염증 반응에 중요한 역할을 한다. 그 중 TNF- $\alpha, \mathrm{IL}-6, \mathrm{IL}-$ $1 \beta$ 가 대표적인 전염증성 사이토카인으로, 전신적 염증 반응 시 증가하여 전사 인자인 $\mathrm{NF}-\kappa \mathrm{B}$ 를 활성화 시키고, 결과적으로 $\mathrm{NO}$, $\mathrm{PGE}_{2}$ 를 비롯한 다른 사이토카인의 생성을 증가 시켜 염증반응 을 지속시키는 것으로 알려져 있다[33]. 이에 본 실험에서는 LPS 자극에 의해 유도된 RAW 264.7 세포에서 증가한 전염증 성 사이토카인 생성에 DLB가 미치는 영향을 조사하였다. LPS $(1 \mu \mathrm{g} / \mathrm{mL})$ 로 유도된 RAW 264.7 세포에 DL과 DLB를 6.25, $12.5,25 \mu \mathrm{g} / \mathrm{mL}$ 농도로 처리한 결과, $\mathrm{DL}$ 추출물은 전염성 사이 토카인에 대한 억제 활성을 보이지 않은 반면 DLB 처리군은 LPS 처리군 대비 TNF- $\alpha$ 를 $18.3 \pm 6.2,27.0 \pm 2.6,37.9 \pm 3.1 \%$, $\mathrm{IL}-6$ 를 $\quad 37.8 \pm 1.2, \quad 50.2 \pm 2.4, \quad 63.8 \pm 1.3 \%, \quad \mathrm{IL}-1 \beta$ 를 $15.5 \pm 2.2$, $32.2 \pm 2.6,47.4 \pm 1.5 \%$ 로 유의한 억제 활성을 나타내었다(Fig. 6). $\mathrm{DLB}$ 는 DL에 비해 향상된 억제 활성을 보였으며, IL-6를 가장 효과적으로 억제하는 항염증 활성을 나타냄을 확인하였다.

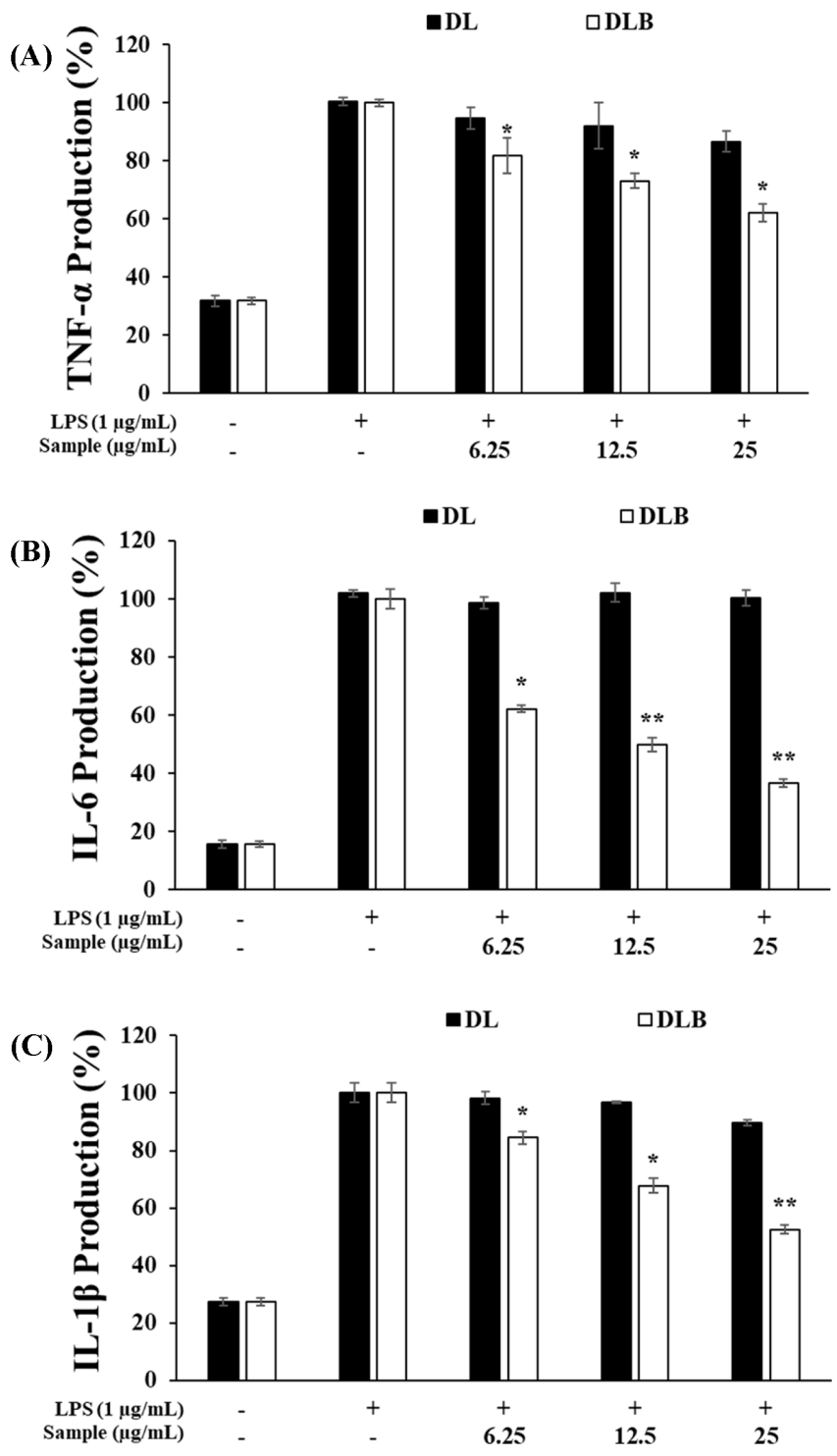

Fig. 6 Inhibitory effects of DL and DLB extract on production of proinflammatory cytokines in RAW 264.7 cells. The production of a) TNF$\alpha, b)$ IL- 6 , and c) IL-1 $\beta$ was assayed in the culture medium of cells stimulated with LPS $(1 \mu \mathrm{g} / \mathrm{mL})$ for $24 \mathrm{~h}$ in the presence of DL and DLB extract $(6.25,12.5$, and $25 \mu \mathrm{g} / \mathrm{mL})$. Results are expressed as a percentage of the control. Data represent the means $\pm \mathrm{SD}$ with three separate experiments. ${ }^{*} p<0.05 ;{ }^{* *} p<0.01$

\section{고 찰}

본 연구는 대식세포의 활성화로 인한 염증반응에서 biorenovation 을 적용한 조록나무 잎 추출물(DLB)이 효과적인 천연물 화장 품 및 기능성 소재로 적용 되기 위한 활용가능성을 검증하기위 해 진행되었다. 이에 RAW 264.7 세포에 LPS를 처리하여 염증 을 유도한 후 $\mathrm{DLB}$ 를 $6.25,12.5,25 \mu \mathrm{g} / \mathrm{mL}$ 농도로 처리하여 $\mathrm{NO}, \mathrm{PGE}_{2}$, 및 $\mathrm{iNOS}, \mathrm{COX}-2$ 그리고 전염증성 사이토카인의 생 
성량을 조사하였다. 실험 결과, DLB는 독성이 나타나지 않는 농도에서 $\mathrm{LPS}$ 에 의해 증가된 $\mathrm{NO}$ 와 $\mathrm{PGE}_{2}$ 를 유의하게 억제하 였으며, DL 대비 향상된 NO 억제 효과를 나타내었다. 또한 $\mathrm{DLB}$ 가 염증 유전자인 iNOS와 COX-2의 발현에 미치는 영향 을 조사하기 위하여 실시된 western blot assay에서 DLB를 처 리한 RAW 264.7 세포는 iNOS 및 COX-2의 발현이 유의하게 감소하였으며, 이는 $\mathrm{NO}, \mathrm{PGE}_{2}$ 생성 억제 효과와 일치하는 결 과로, $\mathrm{DLB}$ 는 COX-2 및 $\mathrm{iNOS}$ 의 발현 억제 기전을 통한 $\mathrm{NO}$, $\mathrm{PGE}_{2}$ 의 생성 감소에 효과적임을 입증하였다. 한편 인체의 염증 반응에는 $\mathrm{NO}$ 와 $\mathrm{PGE}_{2}$ 와 같은 염증 매개물 이외에 필연적으로 염증성 사이토카인이 동반되는데, $\mathrm{DLB}$ 는 이러한 염증매개성 사 이토카인인 IL- $1 \beta$ 와 IL-6의 생성을 유의적으로 억제하였으며, 특히 IL-6의 억제에 가장 효과적인 것으로 확인되었다. 이상의 결과들을 종합하여 볼 때, DLB는 $\mathrm{iNOS}$ 및 $\mathrm{COX}-2$ 의 유전자 발현 감소 작용을 통해 $\mathrm{NO}$ 와 $\mathrm{PGE}_{2}$ 의 생성을 억제하며, 항염 증 효능의 지표 단백질로 알려진 IL- $1 \beta$ 와 IL-6의 분비를 효과 적으로 억제함으로써 기존의 조록나무 잎 추출물에 비해 높은 항염증 활성을 가지는 것으로 판단된다. 이러한 결과는 $\mathrm{DLB}$ 가 다양한 염증 인자를 표적으로 하는 피부 면역 질환의 개선 및 치료와 여러 염증성 질환을 예방하기위한 천연물 화장품 및 기 능성 소재로서의 가능성을 시사하며, 추후 DLB가 더욱 효과적 으로 염증을 억제하는 소재로 사용되기 위해 유효 화합물의 분 리와 동정, 세포 내 염증 관련 기전에 대한 연구가 진행되어야 할 것으로 사료된다. 또한 본 연구의 결과는 천연물을 대상으 로 한 biorenovation의 적용이 생리활성을 향상시키는데 효과적 이며, 보다 안전한 천연 항염증 소재의 발굴에 기여할 수 있을 것으로 사료된다.

\section{초 록}

조록나무는 제주도 및 일본 혼슈 이남, 중국 동남부, 타이완 등 에 분포하는 조록나무과의 상록 교목으로, 항산화 및 tyrosinase, elastase의 억제에 효과적인 것으로 알려져 있지만 $\mathrm{NO}$ 에 대한 억제 효능은 미미한 것으로 보고되었다. 이에 본 연구는 조록 나무 잎 추출물(DL)에 biorenovation 생물 전환 기법을 적용하 여 항 염증 활성을 증진 시키고자 수행되었다. 이들의 활성은 LPS로 자극된 RAW264.7 염증 모델에서 평가 되었으며 NO, inducible nitric oxide synthase (iNOS), cyclooxygenase-2 (COX2) 및 전 염증성 사이토카인에 대한 억제 실험이 수행되었다. 그 결과, biorenovation을 적용한 조록나무 잎 추출물(DLB)는 독 성이 없는 농도에서 $\mathrm{DL}$ 대비 항상된 $\mathrm{NO}$ 와 prostaglandin $\mathrm{E} 2$ 억제 효능을 나타내었으며, 이들의 합성 효소인 iNOS 및 COX-2의 발현에도 유의한 억제 경향을 나타내었다. 또한 대표적인 전 염 증성 사이토 카인인 tumor necrosis factor- $\alpha$, Interleukin 6, Interleukin-1 $\beta$ 에서도 향상된 억제 효능을 확인 하였다. 이러한 결과를 근거로 우리는 biorenovation을 통해 $\mathrm{DL}$ 의 항염증 효능 이 개선될 수 있으며, DLB가 효과적인 천연 항염증 소재로 적 용될 수 있음을 제시한다.

Keywords 조록나무(Distylium racemosum) · 항염증 · Biorenovation - Cyclooxygenase-2 저해 · Inducible nitric oxide synthase 저해
Acknowlegments This research was supported by a grant from the National Institute of Biological Resources (NIBR), funded by the Ministry of Environment (MOE) of the Republic of Korea (NIBR202102109).

\section{References}

1. Kim YH, Song CH (2013) Anti-Inflammatory Effect of Bower Actinidia in LPS-Stimulated RAW264.7 Cells. Society for Meridian and Acupoint 30(4): 243-251. doi: 10.14406/acu.2013.039

2. Jeong HR, Sung MS, Kim YH, Ham HM, Choi, YM, Lee JS (2012) Anti-Inflammatory activity of Salvia plebeia R. Br. leaf through heme oxygenase-1 induction in LPS-Stimulated RAW264.7 macrophages. J. Korean Soc. Food Sci. Nutr 41: 888-894. doi: 10.3746/jkfn.2012.41.7. 888

3. Wynn TA, Barron L (2010) Macrophages: master regulators of inflammation and fibrosis. Semin. Liver. Dis 30: 245-257. doi: 10.1055/ s-0030-1255354

4. Mogensen TH (2009) Pathogen recognition and inflammatory signaling in innate immune defenses. Clin Microbiol Rev 22: 240-273. doi: 10.1128/CMR.00046-08

5. Lim KH, Staudt LM (2013) Toll-like receptor signaling. Cold Spring Harb. Perspect. Biol 5(1): a011247. doi: 10.1101/cshperspect.a011247

6. Dou W, Zhang J, Sun A, Zhang E, Ding L, Mukherjee S, Wei X, Chou G, Wang ZT, Mani S (2013) Protective effect of naringenin against experimental colitis via suppression of Toll-like receptor $4 / \mathrm{NF}-\mathrm{kB}$ signalling. Br. J. Nutr 110: 599-608. doi: 10.1017/S0007114512005594

7. Nathan C (1992) Nitric oxide as a secretory product of mammalian cells. The FASEB Journal 6: 3051-3064. doi: 10.1096/fasebj.6.12.1381691

8. Shao J, Li Y, Wang Z, Xiao M, Yin P, Lu Y, Qian X, Xu Y, Liu J (2013) A novel naphthalimide derivative, exhibited anti-inflammatory effects via targeted-inhibiting TAK1 following down-regulation of ERK1/2- and p38 MAPK-mediated activation of NF- $\kappa B$ in LPS-stimulated RAW264.7 macrophages. Int. Immunopharmacol 17: 216-228. doi: 10.1016/ j.intimp. 2013.06.008

9. Guzik TJ, Korbut R. Adamek-guzik T (2003) Nitric oxide and superoxide in inflammation and immune regulation. J. Physiol Pharmacol 54: 469-487

10. Iwalewa EO, McGaw LJ, Naidoo V, Eloff JN (2007) Inflammation: the foundation of diseases and disorders. A review of phytomedicines of south-african origin used to treat pain and inflammatory conditions. Afr. J. Biotechnol 6: 2868-2885. doi: 10.5897/AJB2007.000-2457

11. McCartney-Francis N, Allen JB, Mizel DE, Albina JE, Xie QW, Nathan CF, Wahl SM (1993) Suppression of arthritis by an inhibitor of nitric oxide synthase. J. Exp. Med 178(2): 749-754. doi: 10.1084/jem.178. 2.749

12. Hippeli S, Elstner EF (1999) Inhibition of biochemical model reactions for inflammatory processes by plant extracts: a review on recent developments. Free Radic Res 31: 81-87. doi: 10.1080/10715769900301361

13. Cho HJ, Shim JH, So HS, YoonPark JH (2012) Mechanism underlying the anti-inflammatory action of piceatannol induced by lipopolysaccharide. J. Korean. Soc. Food. Sci. Nutr 41(9): 1226-1234. doi: 10.3746/jkfn. 2012.41.9.1226

14. Hoffmann C (2000) COX-2 in brain and spinal cord-implications for therapeutic use. Curr. Med. Chem 7(11): 1113-1120. doi: 10.2174/ 0929867003374282

15. Yun HY, Dawson VL, Dawson TM (1996) Neurobiology of nitric oxide. Critical Reviews in Neurobiology 10(3): 291-316. doi: 10.1615/ critrevneurobiol.v10.i3-4.20

16. Kim YS, Lee SJ, Hwang JW, Kim EH, Park PJ, Jeong JH (2012) AntiInflammatory effects of extract from Ligus-trum ovalifolium $\mathrm{H}$. leaves on RAW264.7 macrophages. Journal of the Korean Society of Food Science and Nutrition 41: 1205-1210. doi: 10.3746/jkfn.2012.41.9.1205

17. Park SM, Byun SH, Kim YW, Cho IJ, Kim SC (2012) Inhibitory effect 
of Mori Folium ethanol extract on pro-inflammatory mediator in lipopolysaccharide activated RAW264.7 cells. Korean. J. Herbol 27: 3138. doi: 10.6116/kjh.2012.27.3.31

18. Kim JA, Yang SY, Wamiru A, McMahon JB, Grice SFJL, Beutler JA, Kim YH (2011) New monoterpene glycosides and phenolic compounds from Distylium racemosum and their inhibitory activity against ribonuclease H. Bioorg Med Chem Lett. 21(10): 2840-2844. doi: 10.1016/j.bmcl.2011.03.091

19. Kim HR, Park GN, Jung BK, Yoon WJ, Jung YH, Chang KS (2016) Antioxidant Activity of Solvent Fractions from Distylium racemosum in Jeju. Korean journal of clinical laboratory science 48 (2): 62-67. doi 10.15324/kjcls.2016.48.2.62

20. Ko RK, Kim GO, Hyun CG, Jung DS, Lee NH (2011) Compounds with Tyrosinase Inhibition, Elastase Inhibition and DPPH Radical Scavenging Activities from the Branches of Distylium racemosum Sieb. et Zucc. Phytother. Res 25: 1451-1456. doi: 10.1002/ptr.3439

21. Kim HH, Kwon JH, Park KH, Kim MH, Oh MH, Choe KI, Park SH, Jin HY, Kim SS, Lee MW (2012) Screening of Antioxidative Activities and Anti-inflammatory Activities in Local Native Plants. Kor J Pharmacogn 43(1): 85-93

22. Park SY, Kim JD (2020) A Study on Recognition, Current Use and Satisfaction with Natural Cosmetic Products. KSCC 10(2): 157-172

23. Park TJ, Sim JH, Hong HH, Han DH, Kim SY (2020) Antiinflammatory Effect of Colocasia esculenta Biorenovate Extract in LPSstimulated RAW 264.7 Cells. Korean Society for Biotechnology and Bioengineering Journal 35(2): 162-168. doi: 10.7841/ksbbj.2020.35.2.162

24. Choi BM, Park TJ, Kim JH, Kim SY (2021) The Effect of Brassica napus Biorenovated Extract on the Production of Melanin Production and Tyrosinase Activity in B16F10 Melanoma Cells. Korean Society for Biotechnology and Bioengineering Journal 36(1): 36-41. doi: 10.7841/ ksbbj.2021.36.1.36

25. Choi HR, Park JS, Kim KM, Kim MS, Ko KW, Hyun CG, Ahn JW, Seo JH, Kim SY (2018) Enhancing the antimicrobial effect of genistein by biotransformation in microbial system. Journal of Industrial and Engineering Chemistry. 63: 255-261. doi: 10.1016/j.jiec.2018.02.023

26. Koirala1 M, Lee YK, Kim MS, Chung YC, Park JS, Kim SY (2019) Biotransformation of Naringenin by Bacillus amyloliquefaciens Into Three Naringenin Derivatives. Natural Product Communications. 14(5): 1934578X1985197. doi: 10.1177/1934578X19851971

27. Gilroy DW (2010) Eicosanoids and the endogenous control of acute inflammatory resolution. The International Journal of Biochemistry \& Cell Biology 42(4): 524-528. doi: 10.1016/j.biocel.2009.12.013

28. Kawamata H, Ochiai H, Mantani N, Terasawa K (2000) Enhanced expression of inducible nitric oxide synthase by Juzen-taiho-to in LPSactivated RAW264. 7 cells, a murine macrophage cell line. The American Journal of Chinese Medicine 28(2): 217-226. doi: 10.1142/ S0192415X0000026X

29. Yang J, Zhao Y, Shao F (2015) Non-canonical activation of inflammatory caspases by cytosolic LPS in innate immunity. Current opinion in immunology 32: 78-83. doi: 10.1016/j.coi.2015.01.007

30. Masferrer JL, Zweifel BS, Manning PT, Hauser SD, Leahy KM, Smith WG, Isakson PC, Seibert K (1994) Selective inhibition of inducible cyclooxygenase-2 in vivo is anti-inflammatory and nonulcerogenic. Proc. Natl Acad. Sci. USA 91(8): 3228-3232. doi: 10.1073/pnas.91.8.3228

31. Seo WG, Pae HO, Oh GS, Chai KY, Yun YG, Kwon TO, Chung TH (2000) Inhibitory effect of ethyl acetate fraction from Cudrania tricuspidata on the expression of nitric oxide synthase gene in RAW264.7 macrophages stimulated with interferon- $\gamma$ and lipopolysaccharide. Gen. Pharmacol-Vasc. S 35 (1): 21-28. doi: 10.1016/s0306-3623(01)00086-6

32. Sung MS, Kim YH, Choi YM, Ham HM, Jeong HS, Lee JS (2011) AntiInflammatory Effect of Erigeron annuus L. Flower Extract through Heme Oxygenase-1 Induction in RAW264.7 Macrophages. J Korean Soc Food Sci Nutr 40(11): 1507-1511. doi: 10.3746/jkfn.2011.40.11.1507

33. Dendorfer U (1996) Molecular biology of cytokines. Artif Org 20: 437444. doi: 10.1111/j.1525-1594.1996.tb04529.x 